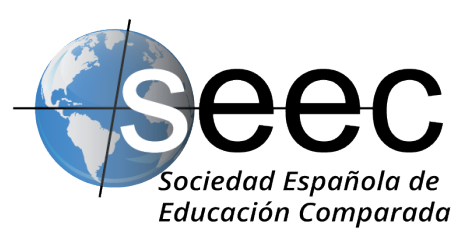

\title{
Re-thinking comparative education and religion: temptations, traditions, and politics*
}

\author{
Repensando la educación comparada y la \\ religión: tentaciones, tradiciones y política
}

\section{Robert Cowen**}

DOI: $10.5944 /$ reec.33.2019.22229

\author{
Recibido: 22 de junio de 2018 \\ Aceptado: 20 de octubre de 2018
}

\footnotetext{
* Acknowledgements: The author would like to thank Professor Clara Morgan, Assistant Professor of Political Science at UAE University very warmly, for her generous and rapid response to a rather anxious request for some advice on this article.

**RoBert Cowen is Emeritus Professor of Education in the Institute of Education, University College, London. In the early part of his career he taught in schools and then teacher education in England, later in the State University of New York, Buffalo (SUNY Buffalo) and as a visitor for one or more semesters in the University of La Trobe in Melbourne, the University of Brasilia, the Catholic University of Leuven in Belgium and the Universities of Cambridge and Oxford. His latest publication (2018) is 'Reflections on comparative education: telling tales in honour of Andreas Kazamias.' European Education, 5O(2). Datos de contacto: E-mail: robert.cowen@ucl.ac.uk
} 


\begin{abstract}
This article opens by refusing some traditional ways to approach the theme of comparative education and religion-and-education. Partly, this is because some topics, in terms of religion and education, have been well covered. More generally, there is an explicit refusal of the clichéd assumption that 'comparative education articles' compare (e.g. education systems in Argentina and Australia, or in Brazil and Bolivia; and so on), juxtaposing narratives on any-old-topic which interests the writer, provided the narratives are about two or more different countries. Fortunately, some current changes in the 'epistemic gaze' of comparative education create new levels of theoretical difficulty and permit a break from the classic political equilibrium problem of the liberal secular state juggling education policy choices and juggling competing religious groups. Starting from a different axiom, a sketch of new possibilities is offered. The sketch is theoretically clumsy but it opens up a strategically different way to tell comparative education stories, of the kind which traditionally we have not tried to tell. The conclusion of the article makes a guess about why religion and education might again become a major topic in comparative education.
\end{abstract}

Key Words: comparative education; deductive rationalities; religion

\title{
Resumen
}

Este artículo comienza rechazando algunas formas tradicionales de abordar el tema de la Educación comparada y la religión y la educación. En parte, esto se debe a que algunos temas, en términos de religión y educación, han sido bien cubiertos. En términos más generales, hay un rechazo explícito del supuesto cliché de que los 'artículos de educación comparada' se comparan (por ejemplo, sistemas educativos en Argentina y Australia, o en Brasil y Bolivia, y así sucesivamente), yuxtaponiendo narrativas sobre cualquier tema antiguo que interesa el escritor, siempre que las narraciones sean sobre dos o más países diferentes. Afortunadamente, algunos cambios actuales en la «mirada epistémica» de la educación comparada crean nuevos niveles de dificultad teórica y permiten una ruptura con el problema de equilibrio político clásico del Estado liberal secular que hace malabares con las opciones de política educativa y con los grupos religiosos en competencia. A partir de un axioma diferente, se ofrece un bosquejo de nuevas posibilidades. El boceto es teóricamente torpe, pero abre una forma estratégicamente diferente de contar historias de educación comparativa, del tipo que tradicionalmente no hemos tratado de contar. La conclusión del artículo hace una conjetura sobre por qué la religión y la educación podrían convertirse nuevamente en un tema importante en la Educación comparada.

Palabras clave: Educación comparada; racionalidades deductivas; religión 


\section{Temptations}

This article does not begin with religion. It begins with sociology: T.H. Marshall made a distinction (in his Inaugural Lecture at the London School of Economics and Political Science in 1946) between 'the way to the stars' and 'the way to the sands'. He imagined a sociologist who was a slave to concepts; and a sociologist who was a slave to methods. The distinction still has power, seventy years later. It illuminates what is happening to English sociology of education and other branches of educational studies in current $\mathrm{PhD}$ and EdD training programmes; but it also helps in taking decisions about writing articles. This one will aim to get a bit above ground level, but not so much that vertigo sets in.

Thus the article will step back from the task of tackling comparative education and religion on a world-wide basis: it will step back from tracing, for example, the complex relationships of religion and education within international programmes for Education For All (Marshall, 2010) or trying to re-think the relations of religion and the education of women (King, 1987). The speed with which those two themes and their literatures is changing in the hands of specialists, including feminists, is impressive. Tackling those themes would be an act of hubris.

Similarly, the article will step back from what, in comparative education terms, is 'the way to the sands': an over-interpretation of 'comparative' and 'education' that creates the simplistic definition that 'comparative education' must be narratives about one society and descriptions of its 'educational system'[sic] juxtaposed with (compared against) another society and descriptions of that educational system[sic]. Comparative education as a field of study is a bit more complicated than that.

The matching temptation, which is another invitation to do routine comparative work, is to look at the domestic - here, the theme of the United Kingdom itself, partly because the United Kingdom is axiomatically 'a comparison' in its own right. Such a comparison would involve narrating something about four nations and outlining the different religious traditions of England, Northern Ireland, Scotland, and Wales. Within that account, it would also be necessary to describe minority and immigrant-minority groups whose religions are acknowledged in the publicly-funded educational system and within the private school sector that includes Catholic, Jewish and Muslim schools. However, any new narration of this kind (even of a complex case like the UK), were it well done, might add to the tradition and literature on the theme of comparative education and religion - but it is unlikely to disturb it.

\section{Traditions: some of the literature}

Certainly, there has been a lot of 'comparative' narration. In the history of comparative education, the theme of religion-and-education has been important. A conventional signal of that is whether the topic was covered within one of the (World) Yearbooks of Education which were part of cooperation between the comparative education departments of the Institute of Education of the University of London and Teachers College, Columbia. And, yes, there is indeed a volume devoted to the theme of religion and education, edited by George Bereday of Teachers College, Columbia and Joseph Lauwerys of the Institute of Education in the University of London (1966).

The tradition of looking at religion and education is, however, older than that. It is very visible in the writing of scholars such as Isaac Kandel $(1933 ; 1936)$ and Nicholas 
Hans. Indeed 'religion' was one of Nicholas Hans' "factors" which he outlined in his major book (1959) that constructed a classic perspective within the academic study of comparative education. His ideas became one of the basic, traditional, ways to think comparatively using the perspective of history. (Hans' other factors included language, race, geographic and economic circumstances, and political philosophes.) All, in various combinations, were and are powerful framing forces of educational systems.

In other words, within an historical comparative education gaze, religion can be shown to be one of the 'forces and factors' which was a major influence in defining identity and 'education': the expansion of Buddhism to China; the territorial explosion of the new faith of Islam which took it along the Mediterranean rim, south into Africa, and north into Spain; the mix of religions on the Indian sub-continent surviving well enough until the catastrophe after the very hasty withdrawal of the British at the beginning of the end of the imperial era. There has also the theme of bitter tensions between faiths (Jews as a community were massacred in England in the city of York as early as 1190 - an indirect part of the mass hysteria called The Crusades) and hatred within faiths, such as the fundamentalist desecration of images within Christian cathedrals at various points in European history; Protestants burning Catholics at the stake and vice versa. All this is well known and had clear impact on peoples' lives - and on art, music, architecture, languages, forms of writing, science, and assumptions about education.

Historically, political power and religion are often inter-twined; though the Roman Empire was remarkably tolerant of most (if not all) religious sects within the principle of 'render unto Caesar...'. In contrast, religion was an integral part of the expansion of the Spanish and Portuguese empires, most dramatically perhaps in South America. Other Empires - such as the British, the French, the Russian, and the late nineteenth century expansion of the American 'empire' outside of the continental United States - all had different mixtures and tensions between the secular motifs of Empire and the work of religious missionaries and decisions about what would count as 'education'. Those relations between religion and education - a motif in most empires - had quite dramatic variations. For example, Jesuits were among the early arrivals from Portugal to Brazil. In contrast, the British Empire in India began in trade. The East India Company, licensed to trade by the British State, kept extending its trading empire (sometimes with the use of military force) until the governance of 'India' - understood as a sub-content rather than in its contemporary definition - was finally taken over by the British Government. Thereafter, in India, the religious enthusiasms of the Christian missionaries especially in the nineteenth century (and the religious motifs within what the British chose to call 'The Mutiny' in 1857) meant that Christian missionary movements, despite their popularity at home in Britain, were often seen by British administrators in India as a bad influence: one which made calm governance of a complex sub-continent difficult.

Contemporaneously, variations around the 'religious question' continue. For example, it remains clear that in Northern Ireland the theme of identity in terms of the tension of nationality AND religion underpins many of the disputes between the 'nationalists' and the 'unionists', as these are represented in Northern Ireland by the political parties of Sinn Fein and the Democratic Unionist Party. For example, it remains clear that in the United States (even if we ignore the astonishingly frequent invocation of God, in public, by American politicians) there were still in the twentieth century considerable tensions between religion-based and science-based interpretations of the world. In schools, what may be taught to children continues within a classic struggle between 
evolution-and-science and extreme versions of religious belief, as the proper way to discuss 'man and nature'. For example, a powerful mix of religious and nationalist views and tragedies of violence continue in Afghanistan and Egypt, in Nigeria and the Yemen, in the former Yugoslavia and in Syria. Nor are more gradualist forms of adjustment between the past and the present, the relation of the secular and the religious, easy: for example, the tension between secular and religious-based versions of the Turkish State is a tension which has gone in and out of sharp focus, almost malevolently, since the secularisations of Turkey by Kemal Atatürk.

Thus, given such well known indications of the political and cultural, sociological and economic visibility of religion in contemporary affairs, it might be expected that, within comparative education, religion would be given regular and serious attention. It has been give serious attention, but that attention has not been regular: the major scholarly books on religion and education have not tried to offer an explicit comparative perspective: de Souza, Durka, Engebretson, Jackson \& McGrady (2006); Catholic (Grace \& O’Keefe, 2007), Islamic (Daun \& Arjmand, 2018), Jewish (Miller, Grant \& Pomsom, 2011) and Protestant education (Jeynes \& Robinson, 2012). There is also literature in which the theme of religion is very important as a sub-theme but where a comparative motif is not explicit (for example in the World Yearbook Education on Intercultural Education edited by Coulby, Jones and Gundara (1997).

One or two books have treated the theme of religion and education by the classical tactic of juxtaposition of narratives about various countries. One such book is edited by Charl Wolhuter and Corene de Wet (2014) with an opening essay by de Wet that sets out the themes of the book. The countries given attention - in fairly loose coupling, with considerable variation in the sub-themes of the chapters - are Armenia, Israel, Tanzania, the United States, the Netherlands, Greece, Brazil, South Africa, Japan, Malaysia and Iran (though this last chapter in the book takes the form of a bibliographic essay). Another relatively recent book, by Keith Watson and Bill Ozanne (2012) who are two well-know British specialists in international and comparative education, contains some reprinted articles: Katherine Marshall (2010) and an article by Watson and Ozanne (2010) themselves - for the obvious reason that the organising question of the book follows the title of their earlier article: 'education, politics and religion: can they ever be separated?' Answers are provided in three chapters which look at (different) aspects of the education of Christians in different places; a chapter on Jewish and non-Jewish education in Israel; an analysis of political Islam and the headscarf with special reference to Turkey; a 'comparative' chapter on the Sikhs in the USA, India and the UK by Bill Ozanne, and a chapter by Kamat and Mathew which spells out a theoretical position and then explores curriculum, in California and in Kerala, to try to interpret the likely consequences of using the pedagogic strategy of a politics of recognition or a politics of redistribution.

The latest book on religion and education within the field of "international and comparative' studies is edited by Malini Sivasubramaniam and Ruth Hayhoe (2018) and looks at 'issues, tensions and possibilities'. In practice, this means that there are three chapters with broad themes (by the editors, by Katherine Marshall who returns to her topic of religion and global education challenges, and and a chapter by Ruth Hayhoe which looks at the interactions of Christianity, Buddhism, and Confucianism). Then there is coverage of a remarkable number of places (Bangladesh, Canada, Kenya, Haiti, Hong Kong, India, Israel, Northern Ireland, Northwestern China, Russia, 
Senegal, South Korea, Tajikistan, Thailand, Western China) with two closing chapters that look at 'diverse and interconnected societies' and a 'cluster analysis of 20 Western democracies.' The sub-themes of the chapters vary with the way in which religion and education is seen by the authors and editors as being important in particular locations, so the sub-themes covered include 'sustainable living', the 'modernisation' of Islam, 'religious extremism', 'desecularization', and 'multiculturalism and school policies and religion'.

Overall, then the theme of religion and education is visible in the contemporary comparative literature without, it may be suggested, being central to it. The tradition of lightly linking education and religion to the theme of multiculturalism remains. There are some changes -- for example the book by Malini Sivasubramaniam and Ruth Hayhoe escapes the tradition of giving a lot of attention to Christianity and a lot of attention to Europe. A changing world is being reported and so far, the study of religion and education has not, fortunately, collapsed into studies of 'evil empires'; this time religious ones. Good, but a slight puzzle remains. Can we get beyond reporting a changing world? Can we 'see' a different world, that is re-think the existing one? How, these days, should we deal with the Watson and Ozanne question: 'education, politics and religion: can they ever be separated?'

To get at these themes ('seeing', 're-thinking'), we need to assess what we are trying to re-think with. In more elegant language, what is the epistemic tradition which has shaped what counts as 'comparative education' and what are its emergent forms, now?

\section{Traditions: comparative education}

It was hinted, earlier, that the field of study of comparative education should not be thought of as being defined simplistically by the 'form' of its texts (Afghanistan-comparedwith-Zanzibar; or by research in which the number of hours of homework undertaken by children in five countries is counted, tabulated, and offered to the world with the word 'comparative' in the title of the research note). Such a definition of 'comparative education' trivialises it.

The traditions of comparative education are complex. Firstly, the field of study is extremely sensitive to the politics of 'the age' (or Zeitgeist if that expression is preferred). For example, between 1930 and 1950, the themes of comparisons of fascism and 'democracy' and 'communism' and education are very visible, as is the sensitivity of comparative education to forms of nationalism and the shaping of educational systems. Secondly, the tradition of comparative education shows major shifts in assumptions about a preferred epistemic gaze (for example 'history' versus 'scientific' thinking: that was a major squabble in the 1960s). The third discontinuity is emerging currently. From 1900 at least - when Michael Sadler asked his classic question 'how far may we learn anything of practical value from the study of foreign systems of education?” (Higginson, 1979) comparative education has been in a reformist stance, worrying about the improvement of educational policy. It still does (Steiner-Khamsi \& Waldow, 2012).

However, that tradition is beginning to change. Partly because of the startling oversimplicities of PISA as a specific type of comparative education (Cowen, 2014a) and its political and educational implications at domestic levels (Auld \& Morris, 2016), and partly because it is more and more clear that - above 'the nation state' - new modes of the governance of educational systems have emerged (Jones, 2007), there is now a strong 
interest in the transnational flows of power which shape educational patterns. What I normally call 'the agenda of attention' of comparative education is edging towards tracing new forms of 'imperium'. This means a strong interest in investigating the transnational mobilities and the shape-changing of educational ideas and practices when they move.

"As it moves, it morphs' (Cowen, 2009a) is a succinct statement of this problem which is an important one because we cannot describe, with any delicacy or complexity, educational 'shape-shifting'. For example, our older vocabularies suggest our educational systems are 'centralised' or de-centralised'; or that our universities are 'public or private'; and so on. Each of these dichotomies is a statement of 'shape' - but of course the reality and complexity of educational shape-changing is outstripping our concepts.

We cannot instantly 'see' shapes. We are not sensitised to them (Cowen \& Klerides, 2009). Yes, we can 'see' that the European Union has had an impact on education and there is good literature on that (Lawn \& Grek, 2012; Nóvoa \& Lawn, 2002). Yes, we have invoked 'globalisation' as an explanatory concept for over two decades (though we have normally edged into oversimplification (Cowen, 2009b). And, yes, we can see that school and university systems are increasingly 'shaped' by international and domestic rankings of educational performance. But we have neither a theory of the sociological and political impact of metrics nor a theory of the new, emerging, 'shapes' of school systems, in which traditional school structures, epistemologies, governance systems, and styles of assessment and evaluation are fracturing.

The challenge is to take up the theme of educational patterns at the intersection of international and domestic politics, and to be alert to 'shape-shifting' - which is likely to disturb those who think comparative education is about juxtaposing narratives of description of educational systems and their 'contexts'; or about assisting in the practical reform of educational systems; or advising the Minister on how to move her (or his) educational system up the competitive ladder, created by PISA.

The challenge is also likely to disturb the literature though two ground-clearing steps might be sensible. A simple first step is to get rid of that conceptual albatross, 'the educational system' which so blocks fresh perspectives in comparative education and legitimates a pragmatic fixation on reform, as if we were politicians or educational administrators -an error which has a long history. Noah and Eckstein (1969), in their teleological account of comparative education moving from 'traveller's tales' to 'a science', gave educational administrators (who looked overseas in the nineteenth century for examples of educational reform - persons such as Horace Mann in the USA or Egerton Ryerson in Canada) major visibility in the history of the field; as if comparative education should aim to become an applied administrative science.

Thus, secondly, a slight re-phrasing is not only useful but necessary: not 'educational systems' but 'educational patterns'. 'Educational patterns' does not axiomatically mean 'the school system', with its elementary and secondary levels and examinations and so on; nor what is taught within it in the name of religion or excluded from it because it is religion; or the 'wrong' religion (Jackson, 2004). The concept of 'educational pattern' is taken, here, as including distinctions between the pure and the polluted, hierarchies of educated identity, the forbidden and the favoured, rituals and rites, and (in Basil Bernstein's phrase) images of conduct, character, and manner. And so, where to start? 


\section{Perspectives}

Perhaps with memories - memories of three books: Voigt's Unto Caesar (1938); Erwin Goffman's concept of 'total institutions' (1968); and Emile Durkheim's Elementary Forms of Religious Life (1995). What was shocking about those books is that they challenged routine forms of analysis and thinking. Thus Voigt's book for example, written in 1938 - and which I read in the 1950s in full knowledge of the bitter struggle between German fascism and Soviet communism in which, literally, tens of millions of people had died - illustrates the sociological similarities of their political systems. Goffman shocks by offering the possibility to see institutions devoted to 'good causes' (such as taking care of the sick or educating people) as places whose sociology constructs peculiar forms of identity and specific styles of oppression. And Durkheim, the son of a rabbi, shows the sociology of the sacred in a way which does not attack the sacredness of religion; but his analysis certainly suspends it.

And, there remains that small question of Watson and Ozanne (2010): 'education, politics and religion: can they ever be disentangled?' The short answer to that is "not often".

The three basic positions are clear: the domination of politics; the domination of religion; and efforts at a balance - typically the secular State with the religious freedoms of the individual being 'guaranteed'.

The third position - a secular State with religious freedoms guaranteed to the individual (about which there is always the occasional crisis and hint of muddle) - is very familiar in the examples of France and the USA, with the paradoxical United Kingdom of Great Britain and Northern Ireland, whose Queen is Head of the Church of England, managing nevertheless to have worked out all sorts of compromises. In the UK and in practice, the State - except in many of its public rituals of governance - functions more or less like a secular State, not least after a major and historic compromise in the 1944 Education Act about what would be taught in the state-financed schools as the only compulsory subject within the curriculum: 'religious education'. (There were minority rights of withdrawal from this compulsory subject, on the grounds of religious affiliation. Unfortunately, individual children did not have the right to withdraw on the grounds of mind-numbing boredom.)

The other two basic State positions tolerate less ambiguity, just as particular individuals might take their identity from Marxism, which locates religion; or a fundamentalist Christian or a fundamentalist Muslim might take their identity from religion, which locates politics. Similarly, with States: Oliver Cromwell's England insisted on religion as a major determinant of politics, as do contemporary Iran and Saudi Arabia. The USSR took politics to be determinant of the position of religion (only a few priestly seminaries of the Russian Orthodox Church were allowed to remain open in the socialist period); clearly the Chinese State remains concerned about the potential political significance of minority religions; as did Japan, with brutal consequences for Christian converts in the early seventeenth century. Obviously, it is possible to give precise examples of these patterns: the point has been pursed with varying degrees of determination in the comparative literature already cited on religion and education. That is true for, say, the Bereday and Lauwerys World Yearbook of Education (1966) up to the contemporary literature, though the literature tips towards illustrating the theme of the officially or constitutionally secular State - after a compromise with organised religion - guaranteeing individual rights to worship. 
However, what if the question 'education, politics and religion: can they ever be disentangled?' becomes 'education, politics and religion: are they the same?' Clearly this has been a real-life goal in some States; though the full fusion so far, with the possible exception of classical Sparta, has always broken. More generally, the point is that the suggestion 'education, politics and religion are the same' (in severally significant sociological ways) gives a sense of shock - but also permits several dimensions of religion and politics and education to be seen in a fresh way.

Here, three such ways will be identified in increasing order of theoretical complexity: illustrations of (a) sociologies of the construction of identity; (b) discursive frames; and (c) symbolic symbioses.

\section{(a) sociologies of the construction of identity}

What we need to be alert to are the ways in which, in politics, in religion, and in education, the construction of identities is captured in roles and rituals, assemblies and processions, and definitions of the pure and polluted within the sociology of institutions. In education in the USSR (and reflecting socialist politics there and in East Germany, etc.), the white shirts and red scarves and Lenin badges of the Octobrists and Young Pioneers in the USSR celebrate a concept of community and socialist modernisation. The formal ties, collars, hats, and the display of small totems - marks of status on the clothes of the English public school boy and English public school girl - reflect future elite status. The nominally romantic (but gender-specific) Wandervögel and strenuous physical exercise - as well as comradeship and explicit political messages - of the Hitler Jugend anticipate a future marked by Lebensraum. All of these ritualised roles define identity rules, the pure and the polluted, and construct a community, as do gender-specific forms of dress encouraged within Islam, and the clothing and gender-framed rituals of various forms of Judaism.

Similarly, in religion, politics and education, processions and music confirm emotionally the nature and hierarchies of a religious, political, and educational community: processions in Greece and Italy and Spain, or Bali and Brazil, mark religious and national identity simultaneously - or as a minimum, religious and local community identity; the processions which attend the formal opening of Parliament in London confirm, in clothing and formal symbolic gestures, the history and hierarchies and political principles of the governance of the United Kingdom. Given the old tradition of English schooling - that the school day opens with a collective act of worship - the processions of staff and selected pupils dressed in formal clothes, walking to carefully chosen music (often religious) confirm a community, both its collective identity and its interior hierarchies. Perhaps one of the more charming rituals of recent interest, is the confirmation of political identity through military parades, allegedly done fairly well in Paris, London, Edinburgh and Moscow; although less so and less frequently it would seem in the USA.

The analogy can be pushed further: religion, educational patterns, and politics all contain sequences: age sequences, clothing-as-uniform sequences, sequences of admission, and perhaps moments of conversion, formal shifts in identities of belonging moments of 'admission' to another identity. Recruitment to the Soviet Komsomol was one such moment in education at the intersection with politics; being awarded the badge of 'prefect' in the English secondary school system was another. In religion there are moments of 'confirmation' and admission to full membership of the religious community - as there are in the admission to 'Party Membership' which usually has hints of special 
honorific status and commitment to action, both in terms of the transmission of the faith and practical effort to build the future - for example the 'cadre schools' of Mao's China.

And finally, 'the faith' almost always involves a 'holy book' - in this instance the Little Red Book of Mao Tse Dong (which - compared to Mein Kampf - had the virtue of being less heavy and so, to great visual effect, it could be waved by converts). In the major organised religions, there is a Holy Book, and mastery of at least some - and sometimes all - of its contents is demanded as a principle for membership. Of course, we do not have that in education, do we? We do. Sometimes the sociological equivalent for admission to the mysteries is Latin; sometimes a display of Marx-Leninist thought; and just as there are hierarchies and several levels of membership of a church beyond a basic ritual of admission (say, baptism or verbal acceptance of conversion), so the basic marker for admission to full membership in formal education is not age - the moment when education becomes an obligation - but the baccalaureat, the vestibular, 'high school graduation' (as in the USA), the Abitur, or the gaining of three A Level subjects (as in England). That is, the moment when 'education' becomes an identity.

\section{(b) discursive frames}

Politics, religions and educational patterns all have the potential to be framed by 'deductive rationalities'. A deductive rationality is a very small number of clear principles from which actions can be deduced (Cowen, 2005) and the pure and the polluted can be defined. For example, Mao's "Learn from the workers, soldiers, and peasants" is a deductive rationality. The point is NOT whether the initial proposition is rational. The point is, if you take the proposition as an axiom - a 'rationality' - then deductions from it can be done relatively easily and relatively systematically (as if the axiom were true).

In politics, in the case of Maoism, this included the closing of schools and universities for a period of two years. In the case of Maoism, this included a theory of what needed to be learned and how it was to be learned and a vision of a social world. To be 'red and expert' meant to acquire a socialist consciousness, and later specific expertise in some branch of labour. And of course the proposition ('Learn from....') contained not merely a definition of a teacher but a pedagogic theory - learning by practical example - and a definition of what was pure and polluted (e.g. bourgeois teachers; with murderous consequences for some individuals at the hands of the Red Guards). In religion (for example, in the radical position of Luther, the Spanish Inquisition, Puritan New England) the basic principles of the religion - which normally include a definition of a social world on this earth - become 'deductive rationalities'. From the basic principles, a very small number of explicit propositions can be deduced, such as 'do not take life' or 'respect all other religions' (or the opposite). These provide a definition of the identity of the believer and are a theory for life-living. Similarly, a teacher - probably specially marked off by status, obvious charisma, training (such as years of meditation), clothing (such as a 'clerical collar', or the robes of a Buddhist novitiate or a monk) - can be publicly identified. But we don't do that in education, do we? We do. In education, the invocation of (economic) globalisation became a deductive rationality within neo-liberal states. This included a theory of what needed to be learned and how it was to be learned; for example, dropping the word 'education' and using the concept 'skills' instead; constructing schools and university systems as a 'market' in which they would 'succeed' i.e. show their own market competence and distribute market competences to students; and defining quality as 
that which can be measured by tests of attainment, rather than be deduced from classic visions of what 'education' is. Of course this neo-liberal 'educational' vision is extreme, but that comes from the confidence of being certain. Certainties always affect education between the wars of the twentieth century, there were the aggressive certainties, and the educational rubrics of Nazism and Communism. After about 1970 we have witnessed the over-confident certainties of extreme forms of the neo-liberal state and its educational prescriptions being read off - as in Australia and England - the deductive rationality of 'economic globalisation'.

Deductive rationalities of these kinds, in politics, in religions, and in education, may provide an extreme definition of the pure and the polluted: heresy and the heretic, though the specific vocabulary of the period might speak of 'enemy of the party', or a category of persons (kulaks in the USSR or 'landlords' in Mao's China) might collectively be so labelled - and punished in the same way as there was clear intent to punish Luther or Henry VIII. But we don't do that in education, do we? Yes, we do. Children get banned from schools. Even a minor criminal act, officially recorded, will ensure an individual may not teach. Tenure in universities usually depends on not being a heretic. Heretics are those who have not absorbed clear messages about 'performativities', whether these be principles of output ('five articles in the top ten journals in the field of study published within five years') or principles of process ('research will be robust': i.e. only empirical research will count as 'quality' research) or principles of relevance: i.e. contribute to policy formation or be sure your work has immediate social and economic impact. Universities in England have established principles and practices which define academic purity: training courses for MA and $\mathrm{PhD}$ students in learning how to do 'robust' research, and in-house training courses for academics in how to be 'relevant'.

Deductive rationalities of these kinds, in politics, in religions, and in education, are likely to provide sharp definitions of time-past and time-future. The confidence of being certain, and the deductive rationalities that go with it, create a messianic sense of things which are wrong with the past (such as a certain kind of image in a Christian church or the existence of Confucian temples, or Buddhist statues - so they should be destroyed). The religious and architectural past itself is judged not merely to be delinquent and dissident; but disposable. There is a moment when 'the present' begins, captured for example in the Christian 'Before Christ' and 'After Christ' as a dating system (even if Anno Domini does not translate literally as 'after Christ'). In politics and in religion, a future is specified; and the future in the secular vision - with the occasional exception (such as a speech by Winston Churchill) - is always good, and in the religious vision often delightful. Political and religious systems both offer definitions of heaven, although one definition is axiomatically secular (the dictatorship of the proletariat; 'independence or death'; or 'the republic'). History is always finishing. But we don't do this in education, do we? Yes, we do. In English educational history there is the messianic moment of the abolition of the 11+ examination and of most of the grammar schools (the selective academic secondary school). A messianic future of common schools for all ('comprehensive schools') beckoned. The Institute of Education itself, within the University of London, was for a moment immersed in a new discourse - as a deliberate ideological move - about 'the old Institute': semi-explicitly under a new Director, there was for a moment a 'New Institute'. The common-sense notion that the 'new Institute' would grow old was lost within the considerable enthusiasms of in-house ideologues. More generally major public moments in education (in England, such as the 1944 Education Act, or the Plowden Report or the 
Robbins Report - but parallels can easily be found for France, Spain, the USA and so on) - are moments which axiomatically define a bad past and a good future.

\section{(c) symbolic symbioses}

Boston in Lincolnshire in England is directly related to the naming of Boston in the United States, as are place names such as Duxbury and Bridgewater and Plymouth and so on; but the relationship is not as romantic and relaxed as it might appear to be at first sight. 'The Pilgrims' who sailed on the Mayflower (and whose descendants are so celebrated in the United States) were a nuisance within existing forms of governance and tradition within Europe - an irritant to the political authorities of both England and the Netherlands. The groups that came to be called The Puritans (persons trying to rid the English Reformed Church of what they judged were the remnants of Catholicism) were political dissidents. Their religious position had gradually became a political position. This pattern, where a religion becomes a politics, has a long history, often marked by blood: the Druids in Wales and Jews at Masada within Roman Empire; as indicted earlier, Christians in Hideyoshi's Japan; the Protestants in the Low Countries and the Spanish Bourbon empire; the Cathars and the violent history of the Languedoc in France; the Mao Mao in Kenya within the British Empire; or the Buddhist protests by priests against the shaping of South Vietnamese society in the mid-1960s by a small Catholic governing elite. The list of illustrations of religion-as-resistance is remarkable: Catholicism in 'communist' Poland; Methodism in England; and cataclysmic events such as the Thirty Years War, the creation of Pakistan, and the fracturing of Yugoslavia which became, like the Holocaust, part of the tragedy of religions and politics. These are situations in which religious identity becomes a political identity. However, many of these situations are not a complex symbiosis but a conflict which becomes binary: one identity does not permit another, except through an act of renunciation and conversion, as with Jews during the Spanish Inquisition.

There is a more complex and very different sociological process which is symbiotic.

Phrasings such as 'political religion' used by Emilio Gentile for Italian fascism (1990; 2005; 2006) hint at serious efforts to decipher the probability that "In modern society, secularization has not produced a definitive separation between the spheres of religion and politics" (Gentile, 1990, p. 229) while along with “.... this process of secularization within both the state and society, there has also been a 'sacralization of politics', which reached its highest point in the totalitarian movements of the twentieth century" (ibid). Interpretive comment about fascism as a political religion goes back, at least among Italians, to the 1920s, includes an assessment of the politics of the Lateran Pact with the Pope, and even permits reinterpretations of Mazzini's ideas and their relation to the Risorgimento. This and other literature makes firm distinctions between the Italian fascist and Nazi and Soviet forms of a 'political religion' (Burleigh, 2007).

Granted then that such reinterpretations of politics now have a considerable history (and that Voigt's work was also brilliantly of its time), we have an important shift in concepts.

The core theme of the classical comparative education literature on religion and education is an equilibrium. Normally, there is a secular State. In places of early revolution, such as France or the USA, or in certain kinds of Empire (the British in India or the Japanese in Korea) or in 'mature democracies' such as Australia or Canada or 
Scandinavia, organised religion (e.g. the Catholic Church or missionaries or the Lutheran Church) is a policy question: it is 'balanced' within a political version of an equilibrium. In other places with a different kind of revolution (as in the USSR) there is a 'crushing' of religion - which is a dramatic collapse of a former political equilibrium of governance. In other places (such as Iran) religion is so dominant the 'the State' disappears, nominally a dramatic collapse of a political equilibrium. This of course is nonsense in an empirical sense (Daun \& Arjmand, 2018). It is also too tight as a theoretical perspective. It is a consequence of thinking in terms of a theory of domestic politics which makes a distinction between the King and the Bishop, between the Holy Roman Empire and the Pope, a dichotomy between the secular and the sacred, between the State as an agency of governmentality and religion as an expression of community, a distinction between temporal and mystical identities.

The second crucial shift - religious modes of shape-changing, the sociological mutation of religions - is extremely well illustrated by Mona Atia (2012): the way in which one religion, Islam, is being re-thought and transmitted in such a way it makes religious sense of the changing world of high modernity and permits coherent action on it and within it. A different shape-changing - illustrated with remarkable subtlety and complexity by Janette Habashi (2011) - indicates how a 'religious identity' became and continues to become an identity of political resistance, while remaining a religious identity. This is a long way, historically and and sociologically and comparatively, from some of the future Pilgrims getting arrested near Boston, Lincolnshire, England on a dark night in 1607. The Pilgrims do symbolise religion-as-resistance in England but they do not symbolise symbiosis. That complexity is marked by more difficult vocabularies, such as the 'sacralisation of politics' and 'pious neoliberalism'.

Thus the final layer in changing the perspective of comparative education on religionand-education is to recognise that what is now called 'education' is a secular ideology which is internationally mobile. The ideology combines an economic rubric about skills and a political rubric about human rights and it is a mobile discourse, a form of the flow of international power. Within Martin Wight's typology of international political relations, it is certainly not an illustration of Hobbesian realism, nor is it 'messianic'. That said, what is in theory a 'rationalist' position is starting to have revolutionary effects 'in the minds of men' (Cowen, 2002) where allegedly 'the defences of peace are constructed.' However the whole of the 'Westphalian position' in international political relations theory is now being seriously discussed (May, Wilson, Baumgart-Ochse \& Sheikh (2014) - which is likely to have considerable implications for theorisation in contemporary comparative education.

In the short term, it is probably no longer possible for analyses in comparative education of 'religion and education' to remain so determinedly domestic, so inter-national, juxtaposing illustrations of policy adjustments and stable and labile and collapsed equilibria of State-and-religion-and educational relations. A world of transnational mobilities and symbolic symbioses beckons and how to think about that is a stern challenge.

\section{Conclusion: perspectives on politics}

It may be clearer by now why this article avoided moving directly to the theme of education-and-religion. The article was emphasising the first half of its title: it was trying to disturb the literature of comparative education itself. One step towards that was noting 
and worrying about some of the traditional but almost invisible assumptions of the comparative religion-and-educational literature: it has tended to be 'comparative' in the simplistic sense - after introductory reflections about education and religion, it has concentrated on (loose) juxtaposition of descriptive narratives; it has tended to be concerned with equilibrium, in the sense of the secular State staying in balance, given 'the problem' of religions; and it has tended to discuss religion when it was a salient policy problem in education, usually within the implicit assumption that comparative education includes a reformist agenda of action.

Indeed that creates a nagging background puzzle which was there from the beginning of the article: why has the theme of religion not remained very close to the centre of the comparative education literature? There are clear reasons why it should be a continuing motif. Those reasons include the need to know the complex relationships between religious background and educational attainment (PEW, 2016) and the emergence of new forms of continuing tensions between secular States and minority religious groups, whether this is in the relationships of fundamentalist Christians in the USA to national politics and new forms of populism, or Muslims in China. The tentative answer of course is that discussion of new kinds of States (both neo-liberal and supra-national States like the EU) displaced traditional themes, such as religion, as an urgent topic. The important world was not the world of religions but the world of economics. 'Globalisation' as an economic system (Held et.al. 1999) has been central to the ways in which much of the comparative education literature and many politicians in many societies have addressed education, until the tweeting of Mr Trump.

As usual, even in this remarkable situation there is a final irony which is offered as a conclusion (though that is exactly what it cannot be). Ironically, it is a new beginning: religion as a theme is returning to the literature in an old disguise.

When I went to study at Trinity College Dublin, as part of my formation as a future teacher, my responsibilities included doing some teaching practice under supervision, the reading books by Plato and Herbart, attending lectures on the history of Irish education, on health education, and on comparative education (and wasting long autumnal afternoons on psychological experiments the point of which - for practical pedagogy could have been explained with total clarity in less than five minutes). So, I was studying in an education course which was solid and sensible (with the exception of the psychological experiments); all quite proper and predictable. However, I was startled towards the end of the first term by a small-group seminar in the Professor's room with a paper given by a student - on Max Weber. I had been reading him, very happily, at the London School of Economics and Political Science where I had just finished my first degree. But Weber in Trinity College, with its Oxbridge atmosphere, the Book of Kells on display, and a promise to be read out in Latin before one could gain membership of the Library? It took a few moments for the click to occur. Teachers in training at Trinity College, Dublin (many of whom might be expected to work overseas in places such as Africa - the health education lectures had included advice on how far apart beds in the dormitories in boarding schools should be placed - were being introduced to Weber's theories about economic growth and Protestantism. Trinity College was very much an Anglo-Irish college, with a tradition of training a Protestant elite within an Ireland that celebrated the Catholic faith. The seminar - and its sociological quality was steady enough - was also cultural and political; a confirmation of religious-political identity. 
Sometime later... it looks as if the theme of religion is about to rescued by the puzzles of 'development' and religion and economic growth. This theme is one motif in the new book, mentioned earlier, edited by Malini Sivasubramaniam and Ruth Hayhoe (2018). But the theme is - almost - central to the brilliant analysis by Mona Atia (2012) which, rooted in the literature of political geography, invents and illustrates the concept of 'pious neoliberalism', faith-based development, and Islam.

So at some time in the future, the irony is that the theme of religion and education may be routinely rescued as a theme of importance - in the international and comparative literature - by failures in economic development (in what used to be called 'the Third World') and by the perennial question: what kinds of religion are linked with relative economic failure and what kinds 'cause' of success? Plus ça change...

But of course it is not really the same thing: religions - Christianity, Hinduism, Islam, Shintoism and so on - and politics, and education shape-shift, implode sociologically into each other, and it becomes necessary to invent new forms of comparative understanding. That, at least in my judgement, is clear. However, what those new forms of comparative education are, or might be, is not.

\section{References}

Atia, M. (2012). "A Way to Paradise": Pious Neoliberalism, Islam, and faith-based development. Annals of the Association of American Geographers, 102(4), pp. 808-827.

Auld, E. \& Morris, P. (2016). PISA, policy and persuasion: translating complex conditions into education 'best practice'. Comparative Education, 52(2), pp. 202-229.

Bereday, G. \& Lauwerys, J. (Eds.) (1966). The World Yearbook of Education: Church and State in education. London: Evans Bros. in association with University of London Institute of Education and Teachers College, Columbia.

Burleigh, M. (2007). National socialism as a political religion. Totalitarian Movements and Political Religions, 1(2), pp. 1-26.

Cairns, J. (2001). Religious perspectives on values, culture and education. In J. Cairns, R. Gardner \& D. Lawton (Eds.), World Yearbook of Education: values, culture and education (pp. 46-66). London: Routledge.

Coulby, D., Jones, C. \& Gundara, J. (Eds.) (1997). World Yearbook of Education 1997: Intercultural Education. London: Routledge.

Cowen, R. (2002). In the minds of men: the shifting contexts of interculturality. In Y. Onghena (Ed.), Interculturel: Balance y perspectives (pp. 171-180). Paris/ Barcelona: UNESCO.

Cowen, R. (2005). Extreme political systems, deductive rationalities, and comparative education: education as politics. In D. Halpin \& P. Walsh (Eds.), Educational commonplaces: essays to honour Denis Lawton. London: Institute of Education, University of London. 
Cowen, R. (2009a). The transfer, translation and transformation of educational processes: and their shape-shifting? Comparative Education, 45(3), pp. 315-327.

Cowen, R. (2009b). Editorial Introduction: the national, the international and the global. In R. Cowen \& A.M. Kazamias (Eds.), International Handbook of Comparative Education (pp. 337-340). Dordrecht: Springer.

Cowen, R. (2014a). Ways of knowing, outcomes and 'comparative education': be careful what you pray for. Comparative Education, 5O(3), pp. 282-301.

Cowen, R. (2018). Narrating and Relating Educational Reform and Comparative Education. In E. Hultqvist, S. Lindblad \& T. Popkewitz (Eds.), Critical Analyses of Educational Reform in an Era of Transnational Governance (pp. 23-39). Dordrecht: Springer.

Cowen, R. \& Klerides, L. (Eds.) (2009). Mobilities and educational metamorphoses: patterns, puzzles, and possibilities [Special issue] Comparative Education, 45(3).

Daun, H. \& Arjmand, R. (Eds. (2018). Handbook of Islamic Education. Dordrecht: Springer.

de Souza, M., Durka, G., Engebretson, K., Jackson, R. \& McGrady, A. (Eds.) (2006). International Handbook of the Religious, Moral and Spiritual Dimensions in Education. Dordrecht: Springer. E. Fields

Durkheim, E. (1995). Elementary Forms of Religious Life (Karen E. Fields, trans.). New York: The Free Press. (Original work published in 1912.)

Gentile, E. (1990). Fascism as Political Religion. Journal of Contemporary History, 25, pp. 229-51.

Gentile, E. (2005). Political Religion: a concept and its critics - a critical survey. Totalitarian Movements and Political Religions, 6(1), pp. 19-32.

Gentile, E. (2006) Politics as Religion. New Jersey: Princeton University Press

Goffman, E. (1968). Asylums. Harmondsworth: Penguin.

Grace, G. \& O'Keefe, J. (Eds.) (2007). International Handbook of Catholic Education: challenges for school systems in the 21st century. Dordrecht: Springer.

Gundara, J. (2000). Religion, human rights and intercultural education. Intercultural Education. 11(2), pp. 127-136.

Habashi, J. (2011). Children's agency and Islam: unexpected paths to solidarity. Children's Geographies. 9(2), pp-129-144.

Hans, N. (1958). Comparative education: a study of educational factors and traditions (3rd ed.). London: Routledge \& Kegan Paul.

Higginson, J. H. (1979). Selections from Michael Sadler: studies in world citizenship. Liverpool: Dejall \& Meyorre. 
Held, D., McGrew, A.G., Goldblatt, D. \& Perraton, J. (Eds.) (1999). Global Transformations: politics, economics and culture. London: Polity.

Jackson, R. (2004). Intercultural Education and recent European pedagogies of religious education. Intercultural Education, 15(1), pp. 3-14.

Jeynes, W. \& Robinson, D.W. (Eds.) (2012). International Handbook of Protestant Education. Dordrecht: Springer.

Jones, P. (Ed.) (2007). Global governance, social policy, and multilateral education [Special Issue 34] Comparative Education, 43(3).

Kandel, I.L. (1933). Studies in Comparative Education. Boston: Houghton Mifflin.

Kandel, I. L. (1936). Comparative Education. Review of Educational Research, 6(4), pp. 400-416.

King, U. (1987). World religions, women and education. Comparative Education, 23(1), pp. 35-49.

Lawn, M. \& Grek, S. (2012). Europeanising education: governing a new policy space. Oxford: Symposium.

Marshall, K. (2010). Education For All: where does religion come in? Comparative Education, 46(3), pp. 273-287.

May, S., Wilson, E. K., Baumgart-Ochse, C. \& Sheikh, F. (2014). The Religious as Political and the Political as Religious: globalisation, post-secularism and the shifting boundaries of the sacred. Politics, Religion \& Ideology, 15(3), pp. 331-346.

Miller, H., Grant, L.D. \& Pomsom, A. (Eds.) (2007). International Handbook of Jewish Education. Dordrecht: Springer.

Noah, H. J. and Eckstein, M. A. (1969). Toward a science of comparative education. New York: Macmillan.

Nóvoa, A. \& Lawn, M. (Eds.) (2002). Fabricating Europe: the formation of an education space. Dordrecht: Kluwer Academic Publishers.

PEW Research Centre (2016). Retrieved from http://www.pewforum.org/2016/12/13/ how-religion-may-affect-educational-attainment-scholarly-theories-andhistorical-background/

Steiner-Khamsi, G. and Waldow, F. (Eds.) (2012). World Yearbook of Education 2012: Policy borrowing and lending in education. London and New York: Routledge, Taylor and Francis.

Sivasubramaniam, M. \& Hayhoe, R. (Eds.) (2018). Religion and education from a comparative and international perspective: issues, tensions and possibilities. Oxford: Symposium.

Voigt, F.A. (1938). Unto Caesar. New York: G. P. Putnam’s Sons. 
Watson, K. \& Ozanne, W. I. (2010). Education, religion and politics: can they ever be disentangled? Comparative Education, 46(3), pp. 267-271.

Watson, K. \& Ozanne, W. I. (2012) (Eds.). Education and Religion: global pressures, local responses. Abingdon: Routledge.

Wolhuter, C \& de Wet, C. (Eds.) (2014). International Comparative Perspectives on religion and education. Bloemfontein: Sun Press. 